\title{
The relationship between cognitive distortions and forgiveness in romantic relationships ${ }^{1}$
}

\author{
Gökçen Aydın ${ }^{2}$ \\ Nasibe Kandemir Özdinç ${ }^{3}$ \\ Meral Aksu ${ }^{4}$
}

\begin{abstract}
The purpose of the present study was to find out the relationship between cognitive distortions and forgiveness in romantic relationships of college students. The sample of the study was 340 college students who have a romantic relationship at a state university in Turkey. The purposeful sampling method was carried out in this correlational study. In order to collect data, three instruments were utilized: Interpersonal Cognitive Distortions Scale (ICDS), Heartland Forgiveness Scale and Demographic Data Form. The scales were put online to survey.metu.edu.tr and students having a romantic relationship were asked to complete the scale. In the present study, canonical correlation was conducted through SPSS 22 statistical package for data analysis in order to assess the relationship between two sets of variables: "Interpersonal Rejection", "Unrealistic Relationship Expectation" and "Interpersonal Misperception" are the subscales of interpersonal cognitive distortions on one set and "Forgiveness of Self", "Forgiveness of Others" and "Forgiveness of Situations" are the subscales of forgiveness on the other set. The study was significant because it might fill the gap in the literature and counseling field in terms of finding the relationship between two sets of variables to give a light to possible predictors in future research studying romantic relationships.
\end{abstract}

Keywords: Romantic Relationship; Cognitive Distortions; Forgiveness; College Students

\footnotetext{
1 Article presented at ECER 2014, Porto.

${ }^{2}$ Middle East Technical University, Educational Sciences, Psychological Counseling and Guidance, agokcen@metu.edu.tr

${ }^{3}$ Middle East Technical University, Educational Sciences, Psychological Counseling and Guidance, nkozdinc@gmail.com

${ }^{4}$ Ph.D. Professor, Middle East Technical University, Educational Sciences, aksume@metu.edu.tr
} 
Aydın, G., Kandemir Özdinç , N., \& Aksu, M. (2015). The relationship between cognitive distortions and forgiveness in romantic relationships. International Journal of Human Sciences, 12(1), 1338-1349. doi: 10.14687/ijhs.v12i1.3206

\section{Introduction}

Human relationship is one of the main needs within the life of human beings (Adler, 2004). In other words, human beings are born into relationships and it is a natural part of human life to have close relations with significant others (Guerrero, Anderson \& Afifi, 201l). Relationships make individuals' life meaningful and satisfactory (Tekin, 2012) and in order to live an optimal life, it is crucial to have meaningful ties of good quality with others (Ryff \& Singer, 2000). While interpersonal relationships are the source of joy and fellowship, they can sometimes make individuals stressful and unhappy ( $\mathrm{Ng} \&$ Tong, 2013). Becker (1992) suggests mutual love, affection and empathy as the key aspects of a good life. Similarly, Griffin (1986) proposes that deep personal relationships sustain a healthy life for people. A romantic relationship is a type of relations in which partners experience love and affection via close ties and they bring positive and negative features of their characteristics to the relationship (Huston, 2009). Within a romantic relationship, partners try to meet both their own and partner's needs which are composed of relationship content like inner feelings, attention, love, trust, conflict, etc. These aspects make the romantic relationships complicated and worth studying in different research because partners are reluctant to bring their interpersonal features into their close relationships.

Among factors influencing relationships, the importance of cognitive distortions' effects on relationships came to the surface with Ellis's emphasis (1986). Since then, the researchers have mostly started to study on cognitive distortions in relationships (Akın, 2010; Hamamc1, 2002, Tufan Çetin, 2010). Cognitive approach focuses on how the individual interprets reality in the relationship and according to cognitive behavioral approach, individuals have some unrealistic and nonfunctional believes about own, others and life. These beliefs; the interpretations made in the relationship, and meanings attributed to the relationship affect relationships, emotions and behaviors of the individuals and the individual behave in dysfunctional way to the partner (Epstein, 1986; Hamamc1, 2002). These wrong thoughts were called as "irrational beliefs" in the model of Ellis, and "authomatic thoughts-cognitive distortions" in the Beck's model. Both concepts including dysfunctional beliefs have dogmatic content which includes patterns that make individual succumb to depression (Türküm, 2003). Automatic thoughts are the most important factors that lead individuals to become anxious and desperate in life (O'connor, Berry, Weiss, \& Gilbert, 2002). Additionally, they also directly affect communication skills, accordingly the human relationships that is a crucial factor of psychological health because individuals are not aware of the thoughts but emotions as the result of these automatic thoughts (Şirin \& Izgar, 2013).

Interpersonal cognitive distortions developed based partly on belief systems and family scripts (Akın, 2010). Couples having many irrational beliefs thought that they have disagreements 
Aydın, G., Kandemir Özdinç , N., \& Aksu, M. (2015). The relationship between cognitive distortions and forgiveness in romantic relationships. International Journal of Human Sciences, 12(1), 1338-1349. doi: 10.14687/ijhs.v12i1.3206

because their relationship is not strong (Tufan Çetin, 2010). Thus, the study results show that decrease of marriage satisfaction of the couples is related with having lots of irrational beliefs and these couples experience much more dissension and stress (Hamamc1, 2005b; Möller \& Zyl, 1991). In addition, these individuals choose to get away and disregard to cope with the problematic situation with their couple, and do not express their anxiety (Tufan Çetin, 2010). Thereby, it is thought that noticing these irrational beliefs would have a positive affect on also romantic relationships.

In any context, an influential component within human relationships is forgiveness. Through years, it is difficult to have a complete definition of forgiveness. By addressing different components of forgiveness, Enright (1991) proposes two necessary processes by including both presenting negative judgment and increasing compassion within the person. Younger et al. (2004) reaches a broad definition by emphasizing four themes allowing negative feelings, accepting and coping with, continuing the relationship and finally forgetting/not forgetting the event. Forgiveness is considered as "an internal, victim-based, voluntary, and multidimensional process; that is, it can involve a variety of targets (e.g., self, others, situations, and conceptions of deity) and methods (e.g., offering, seeking, and feeling) (Webb, Hirsch, Visser, \& Brewer, 2013, p.392)

A number of researches in positive psychology have focused on the importance of forgiveness for its significant benefits on psychological and physical well-being (Thoresen, Harris, \& Luskin, 2000). The studies have shown that forgiveness supports higher life satisfaction, selfesteem, personal productivity, effectiveness, better self-care and conflict management and also it facilitates lower negative affectivity, depression, anxiety, stress and physical illness symptoms (Brown, 2003; Hebl \& Enright, 1993; Lawler et al., 2005; Temoshok \& Chandra, 2000; Temoshok \& Wald, 2005; Toussaint \& Webb, 2005; Worthington, Hook, Davis \& McDaniel, 2011; Ysseldyk, Matheson, \& Anisman, 2007). In addition, forgiveness is characterized as an exclusive method of coping (Toussaint \& Webb, 2005).

Roberts (1995) states that forgiveness leads people to live well specifically in their social environment. That is, forgiveness cannot be concerned as individually, it has an important influence in couple's relationships (Smedes, 1996). Hosseini (2003) and Afkhami (2006) found at the end of their studies that forgiveness increases marital satisfaction of spouses. The empirical study shows that forgiveness interventions decrease cognitive distortions within a relationship and this leads to an increase in marital satisfaction (Navidian \& Bahari, 2013). This shows that cognitive components are essential parts of forgiveness process in relationships. Additionally, as forgiveness has a decreasing effect over interpersonal misconceptions and unrealistic expectations in relationship, it can be determined as a relational healing method (DiBlasio, 1993). 
Aydın, G., Kandemir Özdinç , N., \& Aksu, M. (2015). The relationship between cognitive distortions and forgiveness in romantic relationships. International Journal of Human Sciences, 12(1), 1338-1349. doi: 10.14687/ijhs.v12i1.3206

\section{The purpose of the Study}

Based on the related literature on the possible significance of cognitive distortions and forgiveness in romantic relationships, the purpose of the study was to describe the relationship between cognitive distortions and forgiveness in romantic relationships. More specifically, in the present study, it was aimed at increasing the attention to the forgiveness issue in romantic relationships in early ages by examining how the cognitive distortions were related to individual's forgiveness in their close relationships. Drawing upon the purpose, the research question determined for this study is:

- What is the relationship between interpersonal cognitive distortions (interpersonal rejection, unrealistic relationship expectation, and interpersonal misperception) in predicting forgiveness (forgiveness of self, forgiveness of others, and forgiveness of situations) of college students having a romantic relationship?

\section{Method}

\section{Population and sample selection}

The target population was all college students who had a romantic relationship in Turkey. However, the accessible population was college students having a romantic relationship at Middle East Technical University because the university was convenient for the researchers. As participants should have a criterion as having a relationship, purposeful sampling was used in this study as a non-random sampling method. The scales were put on survey.metu.edu.tr web address and the link was shared on some online web pages of university and written on a paper and distributed to the college students who stay in dormitories and department canteens and they were informed about giving the address to their friends who had also a relationship within the same university. Therefore, also snowball sampling was conducted to reach more participants.

The sample size of the study was 340 college students having a romantic relationship as proposed by Tabachnick and Fidell (2007) (at least 10 observation per variable). Among the participants, 220 of them (64.7\%) were females and 120 of them (35.3\%) were males. The mean of age was 22.99 ranging from 18 to 40 . The students were from five different faculties: education faculty with $27.1 \%$, engineering faculty with $31.8 \%$, economics and administration faculty with $13.5 \%$, art and science faculty with $20.6 \%$ and finally architecture with $7.1 \%$. The relationship duration of the participants ranged from 0 (less than 30 days) to 171 months.

\section{Design of Study}

The purpose of the correlational research was to identify the relationships among variables without any manipulation and to provide a better understanding about the nature of relationships 
Aydın, G., Kandemir Özdinç , N., \& Aksu, M. (2015). The relationship between cognitive distortions and forgiveness in romantic relationships. International Journal of Human Sciences, 12(1), 1338-1349. doi: 10.14687/ijhs.v12i1.3206

among variables (Fraenkel \& Wallen, 2005). As there were two sets of variables within this study, canonical correlation analysis was conducted.

\section{Data Collection}

\section{Data Collection Procedure}

After necessary permission was taken from Ethics Committee of Middle East Technical University, the researchers put the scales on survey.metu.edu.tr web address and the link was shared on some online web pages of the university. At the very beginning of the scales, voluntary participation form was asked to be filled online and then they continued to fill out the questionnaires in reference to the person whom they currently have a romantic relationship. The total administration time of the instruments was approximately 20 minutes. The data was collected in the spring semester and summer school of 2013-2014 academic year.

\section{Data Collection Tools}

Three different instruments were conducted in this study; Interpersonal Cognitive Distortions Scale (ICDS), Heartland Forgiveness Scale (HFS), and Demographic Data Form.

Interpersonal Cognitive Distortions Scale (ICDS): The scale is developed by Hamamc1 and Büyüköztürk (2004) and consists of 19 items to measure individuals cognitive distortions about their relationships. It is a 5 -point Likert scale ( $1=$ totally disagree to $5=$ totally agree). The total score which can be gained from the scale is 95 , and the minimum score is 19 , which indicates that higher points show the individual has higher cognitive distortions about the relationship. The scale consist of three subscales; "Interpersonal Rejection" (8 items), "Unrealistic Relationship Expectation" (8 items) and "Interpersonal Misperception" (3 items), and the reliability analysis of the scale showed Cronbach's alpha levels as .73, .66, .49, for each subscale respectively. Two sample items from the scale are: "People never understand me", and "There is no true friend in this life."

Heartland Forgiveness Scale (HFS): The scale is developed by Thompson, Snyder, Hoffman, Michael, Rasmussen and Billings (2005) to measure an individual's general tendency to be forgiving rather than forgiveness of a particular event or person. The 7-point Likert type scale consists of 18 items with three subscales (Forgiveness of Self, Forgiveness of Others, and Forgiveness of Situations with six items each). The reliability analysis of the scale gives a Cronbach alpha level of $.75, .78, .79$, for each subscale respectively and it is reported as .86 for total score. The scale is translated into Turkish by Bugay and Demir (2010) and the reliability analysis of the Turkish version gives a Cronbach alpha level of $.64, .79$, and .76 , for each subscale respectively and .81 for 
Aydın, G., Kandemir Özdinç , N., \& Aksu, M. (2015). The relationship between cognitive distortions and forgiveness in romantic relationships. International Journal of Human Sciences, 12(1), 1338-1349. doi: 10.14687/ijhs.v12i1.3206

total score. Two sample items from the scale are: "Learning from bad things that I've done helps me get over them.", and "If others mistreat me, I continue to think badly of them."

Demographic Data Form: The demographic data form will be designed by the researcher in order to collect information about gender, age, department and duration of the relationship.

\section{Data Analysis}

In the present study, canonical correlation was conducted through IBM SPSS 22 statistical package for data analysis in order to assess the relationship between two sets of variables: "Forgiveness of Self", "Forgiveness of Others" and "Forgiveness of Situations" were the subscales of forgiveness on one set (Set-1) and "Interpersonal Rejection", "Unrealistic Relationship Expectation" and "Interpersonal Misperception" were the subscales of interpersonal cognitive distortions on the other set (Set-2). Firstly, the descriptive statistics was conducted for this study based on demographic information form. Then, in order to find the relationship between cognitive distortions and forgiveness, canonical correlation analysis was utilized.

\section{Results}

In the study, canonical correlation was utilized due to finding the relationship between cognitive distortions and forgiveness in romantic relationships. The first set included forgiveness of self $(M=26.85, S D=5.46)$, forgiveness of others $(M=23.94, S D=7.43)$ and forgiveness of situation $(M=25.86, S D=7.14)$. The second set included interpersonal rejection $(M=21.19, S D=6.15)$, unrealistic relationship expectation $(M=24.63, S D=5.71)$ and interpersonal misperception $(M=8.20$, $S D=2.31$ ). There were gathered three results of canonical correlation since both of the variables had three subscales. The results of canonical correlation showed that the first canonical coefficient was greater than .30 (Hair, Anderson, Tatham, \& Black, 2010) with a value of .43. Therefore, it was meaningful and used to explain the following results of the analysis $(p<.05)$. The forgiveness (self, others and situations) was significantly correlated with cognitive distortions (interpersonal rejection, unrealistic relationship expectation and interpersonal misperception), $\chi^{2}(9)=.80, p<.05$ in the first canonical correlation, that is only one canonical variate was significant. In sum, the significant correlation was indicated in Table 1. 
Aydın, G., Kandemir Özdinç , N., \& Aksu, M. (2015). The relationship between cognitive distortions and forgiveness in romantic relationships. International Journal of Human Sciences, 12(1), 1338-1349. doi: $\underline{10.14687 / i j h s . v 12 i 1.3206}$

Table1 Correlations, Standardized Canonical Coefficients, Canonical Correlations, Percentages of Variance, and Redundancies between Cognitive Distortions and Forgiveness

\begin{tabular}{lcc}
\hline & \multicolumn{2}{c}{ First Canonical Variate } \\
\cline { 2 - 3 } & Correlations & Coefficients \\
\hline Forgiveness & -.76 & -.42 \\
Forgiveness of Self & -.56 & -.22 \\
Forgiveness of Others & -.90 & -.62 \\
Forgiveness of Situation & .57 & \\
$\quad$ Percentage of Variance & .10 & \\
$\quad$ Redundancy & & \\
Cognitive Distortions & .95 & .94 \\
Interpersonal rejection & .61 & .30 \\
$\quad$ Unrealistic relationship expectation & .30 & -.25 \\
Interpersonal misperception & .45 & \\
$\quad$ Percentage of Variance & .08 & \\
$\quad$ Redundancy & .43 & \\
Canonical Correlation &
\end{tabular}

According to results, canonical loadings for set-1 showed forgiveness of self (-.76), forgiveness of others (-.56) and forgiveness of situation (-.90) and for set-2, interpersonal rejection (.95), unrealistic relationship expectation (.61) and interpersonal misperception (.30). According to Tabachnick and Fidell (2007), correlations higher than .30 are considered as meaningful. This showed that all of the variates in both sets were meaningful. This indicated that as interpersonal rejection, unrealistic relationship expectation and interpersonal misperception increased, forgiveness of self, others and situation decreased. The results showed that cognitive distortions and forgiveness tend to be negatively related. Change in one set was parallel to change in the other set in opposite way.

The strength of the relation between a variate of the equation and its own set of variables is indicated by percent of variance. In the first set, the percentage of values showed that it accounted for $57 \%$ of forgiveness and the second set of variables explained $45 \%$ of cognitive distortions. Finally, the redundancy values account for the variance between a variate of the equation and the other set of variables. Therefore, it can be concluded within this study that $8 \%$ of the variance of the first covariate was explained by cognitive distortions and $10 \%$ of the second covariate was explained by the sets of forgiveness. Figure 1 showed the canonical correlation coefficient and canonical loadings of canonical variates. 


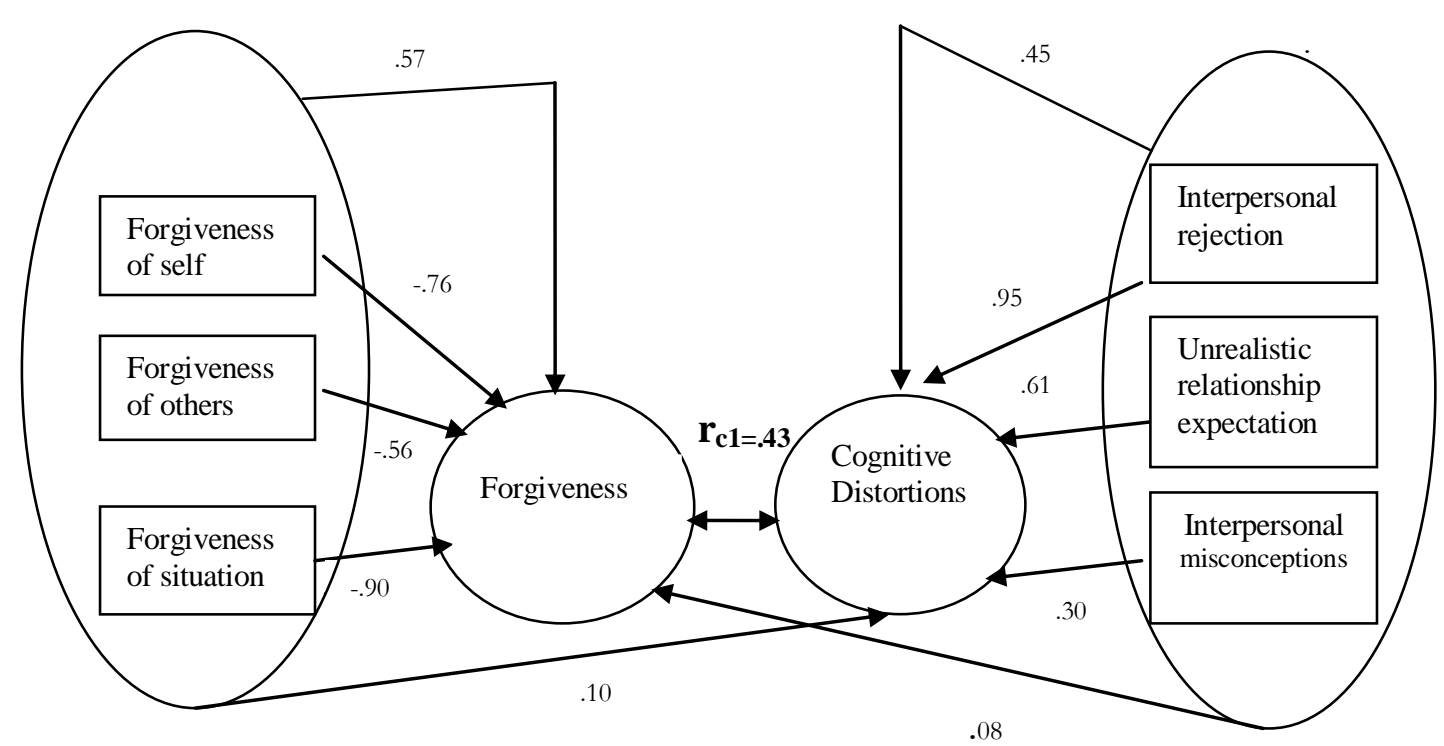

Figure 1 Canonical Correlation Coefficient and Loadings

Finally, the results of the study indicated that there was a negative relationship between cognitive distortions and forgiveness. This meant that while the level of interpersonal rejection, unrealistic relationship expectation and interpersonal misperception increased, forgiveness of self, others and situation decreased for participants having a romantic relationship.

\section{Discussion}

The aim of this study was to examine the relationship between cognitive distortions and forgiveness in romantic relationships of college students since in literature, both concepts were studied within the relationship concept, but especially for married couples. As romantic relationships include different interpersonal features coming from each partner, many studies have been conducted to examine the different variables affecting those relationships. Cognitive distortions and forgiveness were two of the variables studied frequently with married couples. Therefore, this study is significant by including cognitive distortions and forgiveness together for college students having a romantic relationship rather than married couples.

Cognitive distortions were the attempt to interpret the reality and come to unrealistic believes at the end. In the literature, some study results showed that cognitive distortions might affect the relationships in a negative way such as by decreasing marriage satisfaction (Hamamc1, 2002) and relationship satisfaction (Sullivan \& Schwebel, 1995), experiencing stress and disagreement in relationship in couples (Hamamc1, 2005b; Tufan Çetin, 2010). On the contrary, forgiveness is approached as a healing method in relationships with its significance on increasing 
Aydın, G., Kandemir Özdinç , N., \& Aksu, M. (2015). The relationship between cognitive distortions and forgiveness in romantic relationships. International Journal of Human Sciences, 12(1), 1338-1349. doi: 10.14687/ijhs.v12i1.3206

marital satisfaction (Navidian \& Bahari, 2013). Under the light of the information that cognitive components are essential parts of forgiveness process in relationships, this study supported the idea that cognitive distortions were related with forgiveness in romantic relationships of college students.

This result might enlighten that people having a romantic relationship can decrease their cognitive distortions and increase their forgiveness level in order to have more healthy relationships. Therefore, university counseling centers might design some interventions based on forgiveness and try to work on decreasing possible cognitive distortions of students coming with relationship problems. In addition, this study might also give suggestion to counselors working in the field in terms of underlying the importance of cognitive distortions in relationships.

\section{Limitations and Recommendations}

There were some limitations of the present study which needed to be considered. Firstly, generalizability of the results was a limitation for the study. As the participants were only from one university in a city, generalization of the findings was limited with this sample. Secondly, romantic relationships might be influenced by several other variables like gender, age, personality, etc., as mentioned in the literature, but this study only focused on forgiveness and cognitive distortions. Therefore, further studies can be conducted by including other variables in order to find the other possible relationships and/or some possible predictors of forgiveness and cognitive distortions in romantic relationships. Lastly, as the present study design was correlational, it reflected just the presence of possible relationship. Therefore, there can be a need to conduct further studies to find a detailed cause and effect relationship between those variables.

\section{References}

Adler, A. (2004). Yaşamm anlam ve amacı. (Sipal, K.,Trans.) (7th Ed.). Istanbul: Say Publication. (Original work published 1985).

Afkhami I. (2006) The effect of forgiveness training on couples' marital adjustment, marital satisfaction and marital conflicts. A dissertation submitted for Master of Counseling. The University of Isfahan, Faculty of Education and Psychology.

Akın, A. (2010). Self-compassion and interpersonal cognitive distortions. Hacettepe

University Journal of Education, 39, 1-9.

Braithwaite, S., Fincham, F.D. \& Lambert, N. (2009). Hurt and psychological health in close relationships. In A. Vangelisti (Ed.), Feeling Hurt in Close Relationships (376-399). Cambridge: Cambridge University Press.

Becker, L. C. (1992). Good lives: Prolegomena. Social Philosophy and Policy, 9, 15-37. 
Aydın, G., Kandemir Özdinç , N., \& Aksu, M. (2015). The relationship between cognitive distortions and forgiveness in romantic relationships. International Journal of Human Sciences, 12(1), 1338-1349. doi: 10.14687/ijhs.v12i1.3206

Brown, R. P. (2003). Measuring individual differences in the tendency to forgive: Construct validity and links with depression. Personality and Social Behavior, 29, 759-771. doi:10.1177/0146167203029006008

Bugay, A., \& Demir, A. (2010). A Turkish version of Heartland Forgiveness Scale. Procedia Social and Behavioral Sciences, 5, 1927-1931.

Bugay, A., Demir, A. (2011). Hataya ilişkin özelliklerin başkalarını affetmeyi yordaması. Türk Psikolojik Damisma ve Rebberlik Dergisi, 4(35), 8-17.

DiBlasio, F. A. (1993). The role of social workers' religious beliefs in helping family members forgive. Families in Society, 74, 163-170.

Ellis, A. (1986). Rational-emotive therapy applied to relationship therapy. Journal of Rational-Emotive Therapy, 4, 4-12.

Enright, R. D. (1991). The moral development of forgiveness. In Kurtines, W. \& Gewirtz, J. (Eds.), Handbook of moral behavior and development (pp. 123-152). Hillsdale, NJ: Erlbaum.

Epstein, N. (1986). Cognitive marital therapy: multi-level assessment and intervention. Journal of Rational-Emotive Therapy, 1(4), 68-81.

Fraenkel, J. R., \& Wallen, N. E. (2006). How to design and evaluate research in education. Boston: McGraw-Hill.

Gartner, J. (1988). The capacity to forgive: an object relations perspective. Journal of Religion and Health, 27, 313-320.

Griffin, J. (1986). Well-being. Oxford, England: Clarendon.

Guerrero, L. K., Anderson, P. A. \& Afifi, W. A. (2011). Close encounters: Communication in relationships (3rd ed.). Los Angeles: Sage.

Hair, J. F., Black,W. C., Babin, B. J., \& Anderson, R. E. (2010). Multivariate data analysis. USA: Pearson Prentice Hall.

Hall, J. H., \& Fincham, F. D. (2005). Self forgiveness: the stepchild of forgiveness research. Journal of Social and Clinical Psychology, 24, 621-637.

Hamamc1, Z. (2002). Bilissel davranısçl yaklasmla bütünlestirilmis psiko-dramanm üniversite ögrencilerinin kisilerarast iliskilerle ilgili bilissel çarpitmalarn ve temel inançlar üzerine etkisi. Unpublished Doctorate Thesis, Ankara University, Ankara.

Hamamc1, Z. (2005a). Dysfunctional relationship beliefs in marital conflict. Journal of RationalEmotive \& Cognitive-Behaviour Therapy, 23, 245-261.

Hamamc1, Z. (2005b). Dysfunctional relationship beliefs in marital satisfaction and adjustment. Social Behavior and Personality, 33(4), 313-328.

Hamamc1, Z. \& Büyüköztürk, S. (2004). The interpersonal cognitive distortions scale: development and psychometric characteristics. Psychological Reports, 95, 291-303.

Hebl, J. H., \& Enright, R. D. (1993). Forgiveness as a psychotherapeutic goal with elderly females. Psychotherapy, 30, 658-667.

Hosseini A.S. (2003) The correlation of forgiveness between original families and nuclear ones and its relationship with couples' marital satisfactions. Unpublished dissertation submitted for Master of Counseling. University of Wellbeing and Rehabilitation, Department of Counseling \& Psychology, Tehran.

Huston, T. L. (2009). What's love got to do with it? Why some marriages succeed and others fail. Personal Relationships, 16, 301-327.

Lawler, K. A., Younger, J. W., Piferi, R. L., Jobe, R. L., Edmondson, K. A., \& Jones, W. H. (2005). The unique effects of forgiveness on health: An exploration of pathways. Journal of Behavioral Medicine, 28(2), 157-167. doi: 10.1007/s10865-005-3665-2 
Aydın, G., Kandemir Özdinç , N., \& Aksu, M. (2015). The relationship between cognitive distortions and forgiveness in romantic relationships. International Journal of Human Sciences, 12(1), 1338-1349. doi: 10.14687/ijhs.v12i1.3206

Möller, A.T., \& Zyl, D.V. P. (1991). Relationship beliefs, interpersonal perception, and marital adjustment. Journal of Clinical Psychology, 47, 28-33.

Navidian, A. \& Bahari, F. (2013). The impact of mixed, hope and forgiveness-focused marital counseling on interpersonal cognitive distortions of couples filing for divorce. Journal of Psychiatric and Mental Health Nursing, 1-9, doi: 10.1111/jpm.12058.

$\mathrm{Ng}$, A.S. \&. Tong, E.M.W. (2013). The relation between implicit theories of personality and forgiveness. Personal Relationships, 20, 479-494. doi: 10.1111/j.1475-6811.2012.01419.x

O’Connor, L. E., Berry, J. W., Weiss, J., \& Gilbert, P. (2002). Guilt, fear, submission, and empathy in depression. Journal of Affective Disorder, 71, 19-27.

Roberts, R. C. (1995). Forgivingness. American Philosophical Quarterly, 32, 289-301.

Ryff, C. D. \& Singer, B. (2000). Interpersonal flourishing: A positive health agenda for the new millennium. Personality and Social Psychology Review, 4, 30-44.

Smedes, L.B. (1996). Forgive and Forget: Healing the Hurts We Don't Deserve. San

Francisco, CA: HarperSanfrancisco.

Subkoviak, M. J., Enright, R. D., Wu, C.-R., Gassin, E. A., Freedman, S., Olson, L. M., \& Sarinopoulos, I. (1995). Measuring interpersonal forgiveness in late adolescence and middle adulthood. Journal of Adolescence, 18, 641-655.

Sullivan, B. F. \& Schwebel, A. I. (1995). Relationship belief and expectations of satisfaction in marital relationships: Implications for family practitioners. Family Journal, 3, 298-305.

Şirin, H. \& Izgar, H. (2013). Relationship between undergraduates' communication skills and their negative automatic thoughts. Elementary Education Online, 12(2), 585-596.

Tabachnick, B.G. \& Fidell, L.S. (2007). Using Multivariate Statistics. (5th ed.) Boston: Pearson.

Tekin, I. (2012). Kişileraras Güller Envanterinnin (Inventory of Interpersonal Strengths) Türk üniversite ögrencilerine uyarlanmasi: Dilsel eşdeğerlik, gegcerlik ve güvenirlik çalısması. Unpublished Master Thesis, Marmara University, Istanbul.

Temoshok, L. R., \& Chandra, P. S. (2000). The meaning of forgiveness in a specific situa- tional and cultural context: Persons living with HIV/AIDS in India. In McCullough, M.E., Pargament, K.I. \& Thoresen, C.E. (Eds.), Forgiveness: Theory, research, and practice (pp. 4164). New York: The Guilford Press.

Temoshok, L. R., \& Wald, R. L. (2005). Forgiveness and health in persons living with HIV/AIDS. In Worthington, E.L. (Ed.), Handbook of forgiveness (pp. 335-348). New York: Routledge.

Thompson, L. Y., Snyder, C. R., Hoffman, L., Michael, S. T., Rasmussen, H. N. \& Billings, L. S. (2005). Dispositional forgiveness of self, others, and situations. Journal of Personality, 73, 313-359.

Thoresen, C. E., Harris, A. H. S., \& Luskin, F. (2000). Forgiveness and health: An unanswered question. In McCullough, M.E., Pargament, K.I. \& Thoresen, C.E. (Eds.), Forgiveness (pp. 254-280). New York: The Guilford Press.

Toussaint, L. \& Webb, J. R. (2005). Theoretical and empirical connections between for- giveness, mental health, and well-being. In Worthington, E.L. (Ed.), Handbook of forgiveness (p. 349362). NY: Routledge.

Tufan Çetin, B. (2010). Evlilik doyumunun bą̦ değiskkenlere göre yordanması. A dissertation submitted for Master of Counseling. Ege University, İzmir.

Türküm, S. (2003). Akılcı olmayan inanç ölçeğinin gelistirilmesi ve kısaltma çalısmaları. Türk Psikolojik Danisma ve Rehberlik Dergisi, 19, 41-47. 

romantic relationships. International Journal of Human Sciences, 12(1), 1338-1349. doi: 10.14687/ijhs.v12i1.3206

Webb, J.R., Hirsch, J.K., Visser, P.L. \& Brewer, K.G. (2013). Forgiveness and health: Assessing the mediating effect of health behavior, social support, and interpersonal functioning. The Journal of Psychology, 147(5), 391-414.

Wenzel, M. \& Okimoto, T.G. (2012). The varying meaning of forgiveness: Relationship closeness moderates how forgiveness affects feelings of justice. European Journal of Social Psychology, 42, 420-431. doi: 10.1002/ejsp.1850.

Wong, S. S. (2008). The relations of cognitive triad, dysfunctional attitudes, automatic thougts, and irrational beliefs with text aniety. Curr Psychol, 27, 177-191.

Worthington, E. L., Hook, J. N., Davis, D. E., \& McDaniel, M. A. (2011). Religion and spirituality. Journal of Clinical Psychology, 67, 204-214. doi:10.1002/jclp.20760.

Younger, J. W., Piferi, R. L., Jobe, R. L., \& Lawler, K. A. (2004). Dimensions of forgiveness. Journal of Personal and Social Relationships, 21, 837-855.

Ysseldyk, R., Matheson, K., \& Anisman, H. (2007). Rumination: Bridging the gap between forgiveness, vengefulness, and psychological health. Personality and Individual Differences, 42, 1573-1584. doi:10.1016/j.paid.2006.10.032. 